\title{
Isolated ACTH Deficiency Associated with Hashimoto's Thyroiditis : Report of a Case
}

\author{
Kazuomi Hori, MD, Yukihiko AdachI, MD, Norihiko Aoki, MD \\ and Toshio Yamamoto, MD
}

\begin{abstract}
A 65-year-old female with general malaise, anorexia and marked emaciation was studied by secretion stimulation tests on 6 anterior pituitary hormones. Only ACTH showed no response and the other 5 hormones responded normally. The basal value of antidiuretic hormone was normal. She was found to be suffered from primary hypothyroidism. Though neither antithyroid antibodies nor other autoantibodies were found, Hashimoto's thyroiditis was confirmed by a thyroid open biopsy. Neoplastic lesions of the hypophysis were ruled out by various X-ray and CT examinations of the sella turcica as well as the brain. The case was concluded to be isolated ACTH deficiency associated with Hashimoto's thyroiditis. The substitution therapy using small doses of adrenocortical hormone and thyroid hormone has kept her well and she has been living normally for these five years.
\end{abstract}

Key Words: Hypophysis, Thyroid biopsy, Isolated ACTH deficiency, Hashimoto's thyroiditis

Isolated ACTH deficiency is a rare disease and a very small portion of the cases are associated with specific complications. The complications reported so far include diabetes mellitus ${ }^{1}$, acute intermittent porphyria ${ }^{2)}$, and inadequate secretion of antidiuretic hormone $\mathrm{e}^{3,4)}$. Chronic thyroiditis has appeared as a complication in three reported cases so $\mathrm{far}^{5-7)}$. However, in two cases which underwent endocrinological tests thyroid glands were not examined histologically ${ }^{6,7)}$, in the third the gland was examined histologically in detail at autopsy but not endocrinologically ${ }^{5)}$. We here report a case of isolated ACTH deficiency associated with Hashimoto's thyroiditis which was diagnosed from both endocrinological and histological examinations.

\section{CASE REPORT}

The patient was a 65-year-old female who managed a grocery store. She had been well until five months before hospitalization, when she had been suffered from occasional headaches and nosebleeds 1-2 times a week, but she did not take any drugs and the symptoms disappeared spontaneously. Three months before the admission, general malaise, a feeling of esophageal obstruction and anorexia had appeared. She lost $10 \mathrm{~kg}$ in weight during 3 months and had marked asthenia. There was no alimentary or hypoglycaemic symptoms and no significant family history.

On admission she was $153.6 \mathrm{~cm}$ tall, weighed $45 \mathrm{~kg}$, and consciousness was clear. Blood pressure 104/80, pulse rate 72 per min, heart and lungs normal. There was no goitre, lymphadenopathy or abnormal pigmentation. Axillary hair was absent, public hair scanty and reflexes relaxed slowly. The PPD skin test gave a $6 \times 5 \mathrm{~mm}$ response with just slight redness. Fasting blood sugar at the time of admission was low at $59 \mathrm{mg} / \mathrm{dl}$. She became hypoglycaemic (glucose of $30 \mathrm{mg} / \mathrm{dl}$ ) on the 13th day of hospitalization after fasting for a morning.

White blood cell count of $5,200 / \mathrm{mm}^{3}$, a red

From The Second Department of Internal Medicine, Kinki University School of Medicine, Osaka, Japan.

Received for publication June 27, 1983.

Reprint request to: Kazuomi Horii, MD. The Second Department of Internal Medicine,

Kinki University School of Medicine, Sayama-cho, Minamikawachi-gun, Osaka, 589, Japan. 
blood cell count of $332 \times 10^{4} / \mathrm{mm}^{3}$ and $\mathrm{Hb}$ of $9.4 \mathrm{~g} / \mathrm{dl}$, indicating normocytic and normochromic anemia. In the bonemarrow examination, there were findings of hypoplasia. The total serum protein was $5.3 \mathrm{~g} / \mathrm{dl}$ (normal range: 6.5-8.4). Serum $\mathrm{Na}$ was $127-132 \mathrm{mEq} / \mathrm{L}(135-145)$ but $\mathrm{K}, \mathrm{Cl}, \mathrm{Ca}$ and inorganic phosphorus normal, gamma-globulin $17.6 \%$ (normal). Assays of the immunoglobulins (IgG, A, M and D) and the complement levels for $\mathrm{C}_{3}$ and $\mathrm{C}_{4}$ were normal. Tests for LE cells, RA factor, antinuclear antibodies, anti-DNA antibodies, anti-thyroidal microsome antibodies and anti-thyroglobulin antibodies were all negative.

\section{ENDOCRINOLOGICAL TESTS}

\section{METHOD}

1) Pituitary function tests

LH and FSH were measured after intravenous injection of $100 \mu \mathrm{g}$ of LHRH. PRL and TSH were measured after intravenous injection of $200 \mu \mathrm{g}$ of TRH. GH and ACTH were measured after induction of hypoglyceamia by intravenous administration of 0.1 unit $/ \mathrm{kg}$ of regular insulin. 2) Pituitary-adrenal function tests

Serum cortisol was measured 4 and 8 hours after administration of synthetic ACTH (Cortrosin $\mathrm{Z}, \quad 0.5 \mathrm{mg}$ intramuscular). Serum cortisol and urinary 17-OHCS were measured for the samples obtained after 8 hours on the day and after two days of administration of synthetic ACTH (Cortrosin, $0.25 \mathrm{mg}$ resolved physiological saline solution of $500 \mathrm{ml}$ and dropped intravenously for 8 hours). Also, they were measured during two days and one day after the administration of metyrapone (500 mg orally every 4 hours for two days).

\section{RESULTS}

\section{Basal values}

1) Pituitary system

LH was $75.5 \mu \mathrm{u} / \mathrm{ml}(1-36$, numbers in parentheses indicate normal ranges) and FSH was 112.6 $\mu \mathrm{u} / \mathrm{ml}(1-30)$. PRL was $19.5 \mathrm{ng} / \mathrm{ml}(<30)$ and $\mathrm{GH}$ was $1.0 \mathrm{ng} / \mathrm{ml}(<5.0)$. ACTH at 9:00 a.m. was $19.2 \mathrm{pg} / \mathrm{ml}(38-141)$ and TSH was $129.9 \mu \mathrm{u} / \mathrm{ml}$ $(<12)$. The value of ADH was $4.6 \mathrm{pg} / \mathrm{ml}(3-8)$.
2) Adrenal system

The urinary catecholamine excretion was $16.1-35.0 \mu \mathrm{g} /$ day $(9-50)$. Serum cortisol at 9:00 a.m. was $1.0-2.5 \mu \mathrm{g} / \mathrm{dl}(4.5-24)$, urinary 17-OHCS $0.1-1.0 \mathrm{mg} /$ day $(2-8)$ and urinary $17-\mathrm{KS} 2.4 \mathrm{mg} /$ day $(5-10)$. Serum aldosterone was $3-13 \mathrm{pg} / \mathrm{ml}(2-14)$.

3) Thyroid system

$\mathrm{T}_{3}$ was $51-53 \mathrm{ng} / \mathrm{dl}(80-180), \mathrm{T}_{4} \quad 1.9-2.4$ $\mu \mathrm{g} / \mathrm{dl}(7.1-12.7)$ and resin $\mathrm{T}_{3}$ uptake $20.3 \%$ (22-34). Thyroxine-binding protein was 27.3 $\mu \mathrm{g} / \mathrm{dl}(13.1-32.3)$.

\section{Function tests}

LH and FSH showed good, although prolonged, responses to LH-RH. PRL showed a normal response to TRH administration. TSH also showed an exaggerated response although the basal value was higher than normal control (Table 1).

GH showed a normal response to insulininduced hypoglycemia, but ACTH and serum cortisol showed no response to the hypoglycemia (Table 2).

To the intramuscular administration of ACTH, serum cortisol levels showed a good response, increasing from $1.2 \mu \mathrm{g} / \mathrm{dl}$ to $12.8 \mu \mathrm{g} / \mathrm{dl}$ at 4 hours

Table 1. Hormone responses in LHRH and TRH tests

$\begin{array}{rcccc}\text { Time } & \text { LHRH test } & (100 \mu g i . v .) & \text { TRH test } & (200 \mu g i . v .) \\ (\text { min) } & \begin{array}{c}\text { LH } \\ \text { (munit/ml) }\end{array} & \begin{array}{c}\text { FSH } \\ \text { (munit/ml) }\end{array} & \begin{array}{c}\text { PRL } \\ (\mathrm{ng} / \mathrm{ml})\end{array} & \begin{array}{c}\text { TSH } \\ (\mu \mathrm{unit} / \mathrm{ml})\end{array} \\ 0 & 74.5 & 112.6 & 19.5 & 108.9 \\ 15 & 137.4 & 114.6 & 73.5 & - \\ 30 & 226.6 & 144.9 & 81.7 & 235.2 \\ 60 & 241.8 & 154.5 & 67.5 & 214.0 \\ 90 & 273.7 & 168.7 & 67.9 & 218.1 \\ 120 & 234.2 & 176.0 & 51.6 & 169.0(180 \mathrm{~min})\end{array}$

Table 2. Hormone responses to insulin-induced hypoglycemia (0.1 unit $/ \mathrm{kg})$

$\begin{array}{rcccc}\begin{array}{c}\text { Time } \\ (\mathrm{min})\end{array} & \begin{array}{c}\text { Blood glucose } \\ (\mathrm{mg} / \mathrm{dl})\end{array} & \begin{array}{c}\mathrm{ACTH} \\ (\mathrm{pg} / \mathrm{ml})\end{array} & \begin{array}{c}\text { Cortisol } \\ (\mu \mathrm{g} / \mathrm{dl})\end{array} & \begin{array}{c}\mathrm{GH} \\ (\mathrm{ng} / \mathrm{ml})\end{array} \\ 0 & 77 & 19.2 & 2.2 & 1.0 \\ 15 & 40 & 23.3 & 1.3 & - \\ 30 & 42 & 21.1 & 1.1 & 0.7 \\ 60 & 42 & 22.1 & 1.1 & 62.7 \\ 90 & 45 & 20.4 & 1.0 & 62.2 \\ 120 & 45 & 19.7 & 1.2 & 51.8 \\ 150 & 51 & 20.2 & 1.5 & 44.3\end{array}$


Table 3. Pituitary-adrenal function in ACTH and metyrapone tests

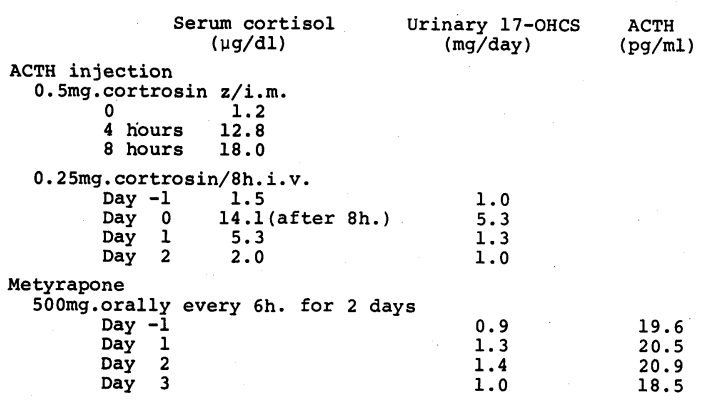

and $18.0 \mu \mathrm{g} / \mathrm{dl}$ at 8 hours. The serum cortisol value increased from $1.5 \mu \mathrm{g} / \mathrm{dl}$ of a basal level to $14.1 \mu \mathrm{g} / \mathrm{dl}$ after intravenous ACTH. Urinary $17-$ OHCS also rose from $1.0 \mathrm{mg} /$ day before ACTH administration to $5.3 \mathrm{mg} /$ day during ACTH infusion, returned to basal level the next day (Table 3).

ACTH and urinary 17-OHCS showed no response on the 1st or 2nd days of metyrapone administration and even on the next day after the completion of the 2 days drug intake programme (Table 3 ).

\section{Histological examination (thyroid open bi- opsy)}

The formation of a germinal center was demonstrated and the thyroid follicles were small and irregular in size. Further magnification showed mild fibrosis of the interstices and diffuse infiltration of lymphocytes. The thyroid follicular epithelium became columnar and in some areas, there was destruction of the epithelia and eosinophilic infiltration. These findings were compatible with those of focal-Hashimoto's thyroiditis (Figs. 1 and 2).

\section{$I V$. Other tests}

There was no abnormality in plain skull X-ray photographs of the sella turcica and CT scans of the brain. The ${ }^{131}$ I uptake rate of the thyroid was increased up to $63.8 \%$ in 24 hours. Gastroscopy revealed chronic atrophic gastritis and a small polyp classified as type II.

Treatments were instituted after completion of all of above tests. Following administration of

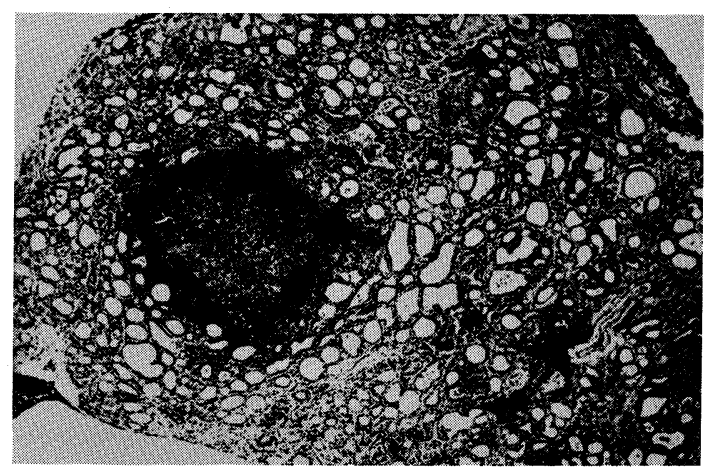

Fig. 1. Middle magnification of the thyroid tissue. Formation of a germinal center is detected and there is shrinkage and degeneration of the thyroid follicles, and clarification of the follicles.

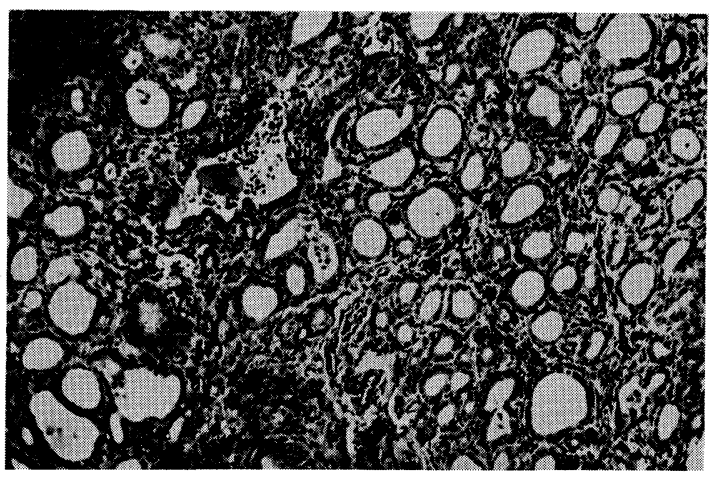

Fig. 2. High magnification of the thyroid tissue. There are mild fibrosis and diffuse infiltration of lymphocytes of the interstices. The follicular epithelium is columnar, and some of the epithelium are destroyed and there are eosinophilic changes.

$7 \mathrm{mg} /$ day of prednisolone and then $0.075 \mathrm{mg} /$ day of L-thyroxine $\mathrm{Na}$ there was a rapid improvement in the symptoms and an increase in body weight. It is five years since the start of the substitution therapy, and her general condition now is consistently normal with TSH of $1.4 \mu \mathrm{u} / \mathrm{ml}, \mathrm{T}_{3}$ of $106 \mathrm{ng} / \mathrm{dl}, \mathrm{T}_{4}$ of $10.4 \mu \mathrm{g} / \mathrm{dl}, 17-$ OHCS of $7.1 \mathrm{mg} /$ day, blood sugar of $97 \mathrm{mg} / \mathrm{dl}$. Her blood pressure is also normal at $140 / 84$.

\section{DISCUSSION}

In this case, general malaise, hypoglyceamic attacks, hyponataemia and hypocortisolaemia 
suggested a decrease in adrenocortical function. Since the administration of ACTH brought about a sufficient increase in serum cortisol and urinary 17-OHCS, it was considered to be secondary adrenocortical insufficiency. Low basal values of ACTH, no ACTH response to both insulin-induced hypoglycemia and the administration of metyrapone suggested ACTH deficiency. The increased values of $\mathrm{LH}$ and FSH were typical of the postmenopause and there was a good response of $\mathrm{LH}$ and FSH to LH-RH stimulation. The responses of TSH and PRL to TRH administration and of $\mathrm{GH}$ to insulin-induced hypoglycemia were normal, as was the basal value of ADH. Plain Xray photographs of the sella turcica and CT scans of the brain showed no neoplastic lesions in the hypophysis. From these results, the case was diagnosed as isolated ACTH deficiency.

TSH showed a good response to TRH with elevation of the basal value. The values of thyroid hormone levels were low and some other thyroid function tests revealed decreased function, which suggested primary hypothyroidism. Histological findings of the tyroid matched those of Hashimoto's thyroiditis, although no anti-thyroid autoantibodies were demonstrated.

There have been many reports of isolated ACTH deficiency, but only three cases were studied with autopsy ${ }^{8-10)}$. These included two cases with decreases in the $\mathrm{R}$ cells and $\beta$ cells in the hypophysis ${ }^{9,10)}$, and one case in which the hypophysis was normal ${ }^{8)}$. It is possible that decrease or disappearance of $\mathrm{R}$ and $\beta$ cells would be caused by reduction in the secretion of corticortropin releasing factor (CRF). It is not clear at this moment if the site of disturbance causing the disease is in the hypophysis or the hypothalamus which produces CRF, although there have been several reports suggesting that the site of lesion is probably located in hypothalamus ${ }^{2,8,11-14)}$. In this context, putative derangements include disorders in the synthesis and/or secretion of CRF, production of anti-CRF antibodies, decreased formation of CRF neurons, etc.

Reports of isolated ACTH deficiency associated with Hashimoto's thyroiditis are extremely rare. However in the reported cases, it has been pointed out, there were common histological abnormalities in both the hypophysis and thyroid. In the autopsy case of Richsmeier ${ }^{5)}$, lymphoid hypophysitis and lymphoid thyroiditis were found together with a selective decrease in ACTH secreting cells. Goudie ${ }^{15}$ ) reported an autopsy case of Hashimoto's thyroiditis and hypophysitis with cellular infiltraton, mainly of lymphocytes. Hume $^{16)}$ reported a case which died of acute renal failure three years after treatment for pernicious anemia. Autopsy revealed infiltration of lymphocytes into the anterior lobe of the hypophysis, the thyroid glands and gastric mucosa respectively, all of which were supposed to be due to common autoimmune disturbances. The lymphoid hypophysitis is not seen in cases of isolated ACTH deficiency alone.

The major difference in the autopsy findings of the hypophysis between isolated ACTH deficiency and the same disorder associated with Hashimoto's thyroiditis is moderate to severe infiltration of lymphocytes in the hypophysis of the latter. Thus, ACTH deficiency associated with Hashimoto's thyroiditis is considered to be caused by lymphoid hypophysitis, and the hypothalamus is not thought to play a major role in etiology. Therefore, isolated ACTH deficiency associated with Hashimoto's thyroiditis seems to be not merely an aggravated condition of isolated ACTH deficiency, but pathogenesis of these conditions is considered to be different from each other.

In the case reported here, autoantibodies of routine procedure were completely negative and there were no increases in immunoglobulins either. It has been proven experimentally that Hashimoto's thyroiditis is caused by an autoimmune mechanism ${ }^{17)}$. But it is also a fact that some of patients with Hashimoto's thyroiditis never prove to be positive in the determination of circulating antithyroglobulin antibody ${ }^{18,19)}$. In cases of isolated ACTH deficiency associated with Hashimoto's thyroiditis reported by Yamamoto $^{6)}$ and Leroith ${ }^{7)}$, neither antithyroidal microsome antibodies nor anti-thyroglobulin antibodies were found. The above facts suggested that the anti-thyroid antibodies or common antibodies of anti-pituitary and anti-thyroid, which can not be recognized by the routine laboratory tech- 
niques, may be present in these cases.

The fact that the patient has returned to a completely normal state in daily life by means of substitution therapy with adrenocortical hormone and thyroid hormone in the observation period over the past five years support that the above diagnosis of this case would be correct.

ACKNOWLEDGMENT: We would like to thank Miss K. Miyasaka for her assistance in the preparation of this manuscript.

\section{REFERENCES}

1) Abramson EA and Arky RA: Coexistent diabetes mellitus and isolated ACTH deficiency: Report of a case. Metabolism 17: 492, 1968.

2) Waxman AD, Berk PD, Schalch D, et al: Isolated adrenocorticotrophic hormone deficiency in acute intermittent porphyria. Annals of Internal Medicine 70: 31 7, 1969.

3) Grant JL, MacDonald A, Brovender SR, et al: Hypoadrenocorticotropism with hyponatremia, resembling antidiuretic hormone excess. Annals of Internal Medicine 63: 486, 1965.

4) Shionoiri H, Yoshii Y, Kato T, et al: A case report of adrenocorticotrophic hormone deficiency associated with the syndrome of inappropriate secretion of antidiuretic hormone. Journal of Japanese Internal Medicine 67: 47, 1978.

5) Richtsmeier AJ, Henny RA, Bloodwoth Jr JMB, et al: Lymphoid hypophysitis with selective adrenocorticotropic hormone deficiency. Archives of Internal Medicine 140: 1243, 1980.

6) Yamamoto $\mathrm{T}$, Ogihara $\mathrm{T}$, Miyai $\mathrm{K}$, et al: Coexistent primary hypothyroidism and isolated ACTH deficiency. Acta Endocrinologica 82: 467, 1976.

7) Leroith D, Broitman D, Svkenik S, et al: Isolated ACTH deficiency and primary hypothyroidism: Volume dependent elevation of antidiuretic hormore secretion in the presence of hyponatremia. Israel Journal of Medical Science 16: 440, 1980.

8) Odell WD, Green GM and Williams RH: Hypo- adrenotropism: The isolated deficiency of adrenotropic hormone. Journal of Clinical Endocrinology 20: $1017,1960$.

9) Perkoff GT, Eik-Nes K, Carnes WH, et al: Selective hypopituitarism with deficiency of anteriorpituitary basophils: A case report. Journal of Clinical Endocrinology 20: 1279, 1960.

10) Saeger W, Mitschke $H$ und Lucking TH: Zytologie der hypophse bei nebennieren-hypoplasie mit hypoglykamie. Deutsche Medizinische Wochenschrift 97: $943,1972$.

11) Hume W and Migeon CJ: Hypoglycemia in a twoyear-old boy with adrenocorticotropic hormone (ACTH) deficiency (probably isolated) and adrenal medullary unresponsiveness to insulin-induced hypoglycemia. Journal of Clinical Endocrinology 28: 146, 1968.

12) Steer P, Marnell $R$ and Werk Jr E: Clinical alchol hypoglycemia and isolated adrenocortrophic hormone deficiency. Annals of Internal Medicine 71: 343, 1969.

13) Ansley A, Moncrieff MW, Ratter S, et al: Isolated ACTH deficiency. Metabolic and endocrine studies in a 7-year-old boy. Archives of Disease in Childhood 53: 499, 1978.

14) Ooi TC, Holdaway IM, Donald RA, et al: Isolated ACTH deficiency confirmed by ACTH radio-immunoassay. Journal of Endocrinological Investigation 3: 45, 1980

15) Gouide RB and Pinkerton PH: Anterior hypophysitis and Hashimoto's disease in a young woman. Journal of Pathology and Bacteriology 83: 584, 1962.

16) Hume R and Roberts GH: Hypophysitis and hypopituitarism: Report of a case. British Medical Journal 27: 548, 1967.

17) Rose NR and Witehsky E: Studies on organ specificity. V. Changes in the thyroid glands of rabbits following active immunization with rabbit extracts. Journal of Immunology 76: 417, 1956.

18) Aoki N, Wakisaka G, Higashi $T$, et al: Clinical studies on thyroidal autoantibodies. Endocrinologica Japonica 22: 89, 1975.

19) Amino $N$ and Degroot LJ: Insoluble particulate antigen(s) in cell-mediated immunity of autoimmune thyroid disease. Metabolism 24: 45, 1975. 